\title{
PLINIJEVO NARAVOSLOVJE IN SREDNJEVEŠKA IKONOGRAFIJA ŽIVALI
}

\begin{abstract}
Ključne besede: srednjeveška ikonografija živali, Plinij starejši, Naravoslovje, bestiariji, Villard de Honnecourt
\end{abstract}

Pomen Plinijevega dela za izoblikovanje srednjeveške ikonografije živali je komajda mogoče pravilno oceniti, saj so poti in načini vplivanja zelo kompleksni in slabo raziskani. Čeprav vodilni poznavalci ikonografije krščanskega naravoslovja ne dvomijo, da so Plinijevi zapisi eden od temeljnih virov za oblikovanje simbolnih pomenov živali, natančnejša opredelitev vpliva še zmeraj ni dokončno izoblikovana. Krščanski pisci, zlasti avtorji bestiarijev, ki so pomembno zaznamovali simboliko živali, vsebine iz $\mathrm{Na}$ ravoslovja pogosto povzemajo brez navajanja vira, drugič spet je očitno, da se v svojem pisanju naslanjajo na antične ali srednjeveške posrednike, ki so naravoslovno znanje črpali iz Plinija, ali pa Plinijeve besede zavestno prikrojijo in dopolnijo tako, kot ustreza njihovemu namenu. Kako torej prepoznati in ovrednotiti Plinijev vpliv, ne da bi zašli v posploševanje in ponavljanje klišejev, ki izhajajo iz pomanjkljivega ali preveč poenostavljenega razumevanje Plinijeve vloge v razvoju ikonografije krščanskega naravoslovja?

Najprej se je treba spopasti z nezadostno raziskanim vprašanjem simbolnih pomenov živali in izhodišč za alegorično interpretacijo, ki jih zasledimo v samem Naravoslovju. Pokaže se, da Plinija simbolne vsebine živali v resnici ne zanimajo in da so preneseni pomeni pri njem zelo redki. Vendar ponuja $\mathrm{z}$ opisi živali in njihovih vedenjskih vzorcev, predvsem pa $\mathrm{z}$ navajanjem zgodovinskih ali mitskih zanimivosti, različnih verovanj in vraž, $s$ katerimi tu in tam popestri svoje pisanje, plodna izhodišča, ki so jih mlajši pisci razvijali dalje in tako prispevali k izoblikovanju živalske simbolike. 
Natančno branje štirih knjig Naravoslovja (knjige 8, 9, 10 in 11), ki jih Plinij posveča živalskemu svetu, kakor tudi odlomkov iz drugih knjig, v katerih omenja živali, ${ }^{1}$ kaže, da raznovrstnih zametkov alegorične interpretacije ne manjka. Vendar bi lahko iskanje simbolnih pomenov ali nastavkov za njihovo oblikovanje v Naravoslovju vzbudilo napačen vtis, da ima Plinij kljub vsemu razmeroma skromen vpliv na poznejši razvoj živalske alegorike. Pomen Plinijevih besed za genezo srednjeveške simbolike živali se namreč dodobra razkrije šele skozi primerjalne analize vseh poznoantičnih in srednjeveških zapisov, ki se ukvarjajo z opisovanjem in/ali razlago živali, njihovega videza in vedenjskih značilnosti. Natančno sledenje rojevanja in oblikovanja določenega simbolnega pomena od izhodišča, ki ga daje Plinij, dodatkov in preoblikovanj njegovih poznoantičnih naslednikov, srednjeveške enciklopedike, biblijske eksegetike, teoloških spisov, moralnodidaktičnih razprav in raznovrstnih drugih zapisov do zrele oblike, kakor jo kodificirajo besitariji, je naloga, ki je še v povojih. Pri tem ne smemo izgubiti izpred oči dejstva, da je raziskovanje razvoja simbolnih pomenov v pisnih virih samo korak k odgovoru na vprašanje o vplivu Plinijevega Naravoslovja na srednjeveško ikonografijo živali, kajti občutljivo področje razmerja med pisnimi viri in pomenom živalskih podob v likovni umetnosti srednjega veka je še vedno odprto.

Davnega leta 1889 je Émile Mâle, veliki francoski umetnostni zgodovinar in eden od pionirjev raziskovanja srednjeveške ikonografije, ob problemu razmerja med živalskimi podobami v likovni umetnosti in pisnimi viri za simboliko živali zapisal: »A kaj spričo bogate favne in flore katedral $v$ Reimsu, Amiensu, Rouenu in Parizu ter spričo skrivnostnega sveta gargouillov? Naj v njih iščemo tudi simbole? Katera knjiga nam lahko razloži njihov pomen? Katero besedilo naj nas vodi? Priznajmo: knjige nam tu ne pomagajo, besedila in upodobitve se ne ujemajo. Če primerjamo ene in druge, ne pridemo do nobenih zanesljivih odgovorov ..." (Mâle, 19104, 41). Mâlevo zadržanost moramo razumeti $\mathrm{v}$ zgodovinskem okviru kot odziv na preveč poenostavljeno stališče nekaterih angleških raziskovalcev, zlasti Johna Romillyja Allena, ki so v bestiarijih videli svojevrstne ikonografske priročnike, $s$ katerimi je mogoče najti razlago za malone sleherno podobo živali

1 Zlasti v knjigah 28-32. 
v srednjeveški umetnosti. ${ }^{2} \mathrm{~V}$ 20. st. so raziskave srednjeveške ikonografije pokazale, da sta tako Allenovo kot Mâlevo stališče ekstremna pola in da je resnica nekako na sredi med obema. Primeri, ko lahko z zanesljivostjo dokažemo neposreden vpliv bestiarijev, so kljub vsemu razmeroma redki, in previdnost je še posebej primerna pri gotski katedralni plastiki, ki jo Mâle posebej izpostavlja. Po drugi strani novejše študije potrjujejo vplivnost bestiarijev na likovno umetnost srednjega veka, in danes $\mathrm{v}$ stroki prevladuje mnenje, da so bestiariji z ustvarjanjem moralno-didaktične živalske alegorike odločilno zaznamovali pomen živali, ki se pojavljajo na različnih področjih upodabljajoče umetnosti. ${ }^{3}$ Kljub novim in novim dokazom o vplivnosti bestiarijev je treba poudariti, da je velik del živalske motivike v srednjeveški umetnosti še vedno ikonografska uganka, ki je ni mogoče povezati $\mathrm{z}$ bestiariji, in da tudi drugi ohranjeni pisni viri ne pojasnjujejo vsebine marsikdaj skrajno nenavadnih živalskih upodobitev.

A vrnimo se $\mathrm{k}$ Pliniju. O aktualnosti njegovega dela v izobraženih krogih visokega srednjega veka pričajo številni prepisi Naravoslovja pa tudi vseprisotno sklicevanje na njegovo avtoriteto na najrazličnejših področjih srednjeveške znanosti. ${ }^{4}$ Avtorji zapisov o živalih niso nobena izjema, navajanje in/ali povzemanje Plinijevih spoznanj je na tem področju še toliko bolj dosledno, ker so vse do 13. st., ko so v latinščino prevedli Aristotelov Nauk o živalih (Historia animalium), ${ }^{5}$ omenjene štiri knjige Plinijevega Naravoslovja veljale za najobsežnejši, najbolj sistematičen, celovit in poglobljen pregled znanja iz zoologije. Ne samo srednjeveški naravoslovci in enciklo-

2 Prim. Allen, J. R., Early Christian Symbolism in Great Britain and Ireland before Thirteenth Century, London, 1887.

3 Med novejšimi deli (z navedbami starejše literature) glej zlasti: Bianciotto, G., Bestiaries $d u$ Moyen Age, Pariz, 1980; Muratova, X., The Medieval Bestiary, Moskva, 1984; Benton, J. R., Bestiaire médiéval. Les animaux dans l'art du Moyen Âge, New York/Pariz/Abbeville, 1992; Voisenet, J., Bestiaire chrétien. L'imagerie animale des auteurs du Haut Moyen Âge ( $V^{e}-X I^{e}$ s.), Toulouse, 1994; Hassig, D., Medieval Bestiaries: Text, Image, Ideology, Cambridge, 1995 in Baxter, R., Bestiaries and their Users in the Middle Ages, London, 1998.

4 Za Plinija in njegov vpliv v srednjem veku glej zlasti: Serbat, G., »Pline l'ancien: Etat présent des études sur sa vie, son oeuvre et son influence«, Aufstieg und Niedergang Römischer Welt, xxxii/4, Berlin, 1986.

5 Prvi prevod Aristotelovega Nauka o živalih je iz leta 1217, ko ga je iz arabščine prevedel Michael Scot, vsestranski učenjak na dvoru cesarja Friderika II. Štaufovca. Prim. Peck, A. L., Aristotle, Historia Animalium, (Introduction), Cambridge, Mass., 1965, xl-xli. 
pediki, temveč tudi pisci moralno-didaktičnih del bolj ali manj posegajo po Pliniju in v njegovih besedah iščejo oporo za svoje izpeljave. Bestiariji kot eden najpomembnejših virov za ikonografijo živali so zgled tovrstnega pristopa. Vendar nas pogosto omenjanje Plinija na straneh bestiarjev ne sme zapeljati k prenagljenim sklepom. Natančnejše branje razkrije, da so za izoblikovanje simbolnih pomenov $\mathrm{v}$ alegoričnih komentarjih, ki v bestiarijih spremljajo opise živali, velikega pomena tudi dela poznoantičnih piscev, ki so povzemali Plinija in njegovim besedam ponekod dodajali metaforične razlage.

Med avtorji 2. in 3. st., ki svoje naravoslovno znanje črpajo pri Pliniju, zaradi vpliva na razvoj srednjeveške ikonografije živali izstopajo Ajlijan s knjigo $O$ značilnostih živalih, Opijan, ki mu pripisujemo pesnitvi O lovu in O ribolovu, in Solin z delom Zbirka znamenitosti. V svojih delih (ki z vidika znanstvene zoologije nimajo posebne vrednosti, saj večinoma nekritično ponavljajo ali povzemajo Aristotelova in Plinijeva spoznanja) razpredajo o značajskih lastnostih živali, natresejo kup nepreverjenih podatkov, zbranih $\mathrm{z}$ vseh vetrov, in vse skupaj začinijo $\mathrm{z}$ domišljijskimi dodatki, ki so imeli daljnosežne posledice.

Branje njihovih zapisov ne pušča nobenega dvoma, da so imeli omenjeni avtorji izostren posluh za alegorično vrednost živali in simbolično pomenljivost njihovih vedenjskih značilnosti. Zanimive nastavke, ki jih v Naravoslovju ponuja Plinij, so Ajlijan, Opijan in Solin spretno dopolnili. Toda za ikonografijo živali je še veliko pomembnejše delo, ki ga $z$ antičnim naravoslovjem povezuje predvsem ime, njegova zasnova pa je radikalno spremenjena. Gre seveda za sloviti spis, ki ga poznamo pod imenom Fiziolog ali Naravoslovec, $\mathrm{v}$ katerem anonimni avtor, ki se sklicuje na neimenovanega »naravoslovca» (kar je spisu dalo ime), združuje zanimivosti iz sveta živali s svetopisemskimi navedki in alegoričnim komentarjem, $s$ katerim dobijo živali jasno opredeljen simbolni pomen. V spisu, ki naj bi nastal v Aleksandriji najverjetneje v 3. ali 4. st., ${ }^{6}$ najdemo odmeve najra-

6 Datacija Fiziologa je še zmeraj sporna in poznavalci glede tega zdaleč niso enotnega mnenja. Vsekakor je prvi latinski prevod nastal pred koncem 5. st., saj je naveden na seznamu heretičnih knjig iz časa papeža Gelazija (Decretum Gelasianum, 496). Številni avtorji njegov nastanek postavljajo v 2. st. n. š., drugi v 3. ali v 4. st. Glej: Sbordone, F., Richerche sulle font $i$ e sulla compositione del Physiologus greco, Neapelj 1936; Offermanns, D., Der Physiologus 
zličnejših del, ki v takšni ali drugačni zvezi omenjajo živali, v navajanju naravoslovnih podatkov pa se močno naslanja zlasti na Aristotela, Plinija in Ajlijana. ${ }^{7}$ Grški izvirnik Fiziologa je izgubljen, znani pa so bizantinski prepisi, prevodi v različne jezike, od armenščine, koptščine in etiopščine do arabščine, gruzijščine, ruščine, stare srbščine idr. Za razvoj srednjeveške ikonografije živali so najpomembnejši latinski prepisi, ki so med 4. in 11. st. nastali na Zahodu. Najstarejši ohranjeni ilustrirani Fiziolog je iz druge četrtine 9. st. in ga hranijo v Burgerbibliothek v Bernu (Ms 318). ${ }^{8}$ Podobo izgubljenega grškega originala lahko dovolj zanesljivo rekonstruiramo s primerjalno analizo ohranjenih prepisov Fiziologa in zgodnjih bestiarijev, ki razmeroma zvesto povzemajo vsebino izvirnega besedila.

Temeljna značilnost Fiziologa je princip alegorične interpretacije živa$\mathrm{li}^{9}$ in njihovega obnašanja, ki je grajena v duhu tipološke razlage Svetega pisma. Starozavezne navedke z živalskimi prispodobami (ali zgolj omembami živali) avtor v tipološkem duhu povezuje s kristološkimi vsebinami nove zaveze, pri čemer simbolični pomen živali dodatno podkrepi (ali v celoti utemelji) z navedbo "znanstvenih dejstev«, ki jih povzema iz zakladnice poznoantičnega naravoslovnega znanja. Tako na primer, se poglavje o jelenu začenja z znamenitim verzom iz 42. psalma: "Kakor jelen hrepeni po potokih vodá, tako hrepeni moja duša po tebi, o Bog «(Ps 42, 2). Zatem avtor navede »dejstvo«, da jelen preganja kače, ki se pred njim skrijejo v svoja podzemna gnezda. Vendar jih jelen izbeza iz luknje tako, da si napolni usta $\mathrm{z}$ vodo in jo brizgne $\mathrm{v}$ kačji brlog, zaradi česar kača prileze na plan, jelen pa jo ubije. V alegoričnem komentarju pisec jelena primerja s Kristusom, ki izžene hudiča iz njegove luknje s tokom besed Božje modrosti, kakor tudi z

nach den Handschriften $G$ und M, Meisneheim, 1966; Henkel, N., Studien zum Physiologus im Mittelalter, Tübingen, 1976 in spremno študijo Otta Schönbergerja v: Physiologus Griechisch/Deutsch, Übersetzt und herausgegeben von Otto Schönberger, Stuttgart, 2001.

7 Po mnenju avtorjev, ki zagovarjajo stališče, da je Fiziolog nastal že v 2. st., naj bi šlo pri vsebinskih paralelah med Fiziologom in Ajlijanom za črpanje podatkov po istih virih, česar pa ni mogoče z zanesljivostjo dokazati.

8 Znameniti Bernski Fiziolog, ki je nastal v Reimsu, je dostopen tudi v faksimilni izdaji: Physiologus Bernensis, voll-Faksimile Ausgabe des Codex Bongarsianus 318 der Burgerbibliothek Bern, izd. Steiger, Ch., Basel, 1964.

9 Fizolog se ne ukvarja izključno z živalmi, temveč vključuje tudi mitsko drevo Perideksion, poglavje o biserih, diamantu in ognjenih kamnih (lapides igniferi), nekatere mlajše različice pa vključujejo tudi več dragih kamnov in dreves. 
vernikom, ki z močjo žive vode, tj. Božje besede, premaga hudiča oziroma greh. Jelen je torej na simbolni ravni izenačen s Kristusom oziroma dobrim kristjanom, kača pa je podoba hudiča oziroma pregrehe, ki pogubi dušo (Fiziolog, 2001, 51-53).

Prepričanje, da jelen preganja kače, da jih izbeza iz njihovih lukenj in jih pobije, najdemo prav pri Pliniju, ki sicer navaja nekoliko drugačno različico: »Jeleni pa so v vojni s kačami; izsledijo njihove luknje in jih s svojo sapo izbezajo iz njih « (Naturalis historia, 8, 50). Plinijev zapis o boju jelenov s kačami povzemajo Plutarh (Moralia, 976 D), Ajlijan (De Natura Animalium, II, 9), Opijan (Kynegetica, II, 233-250) in Solin (Collectanea rerum memorabilium, XIX, 15), navedba pa je bila v rimskem naravoslovju priznana kot nesporno dejstvo. Edini avtor, ki pred Plinijem omenja boj jelenov s kačami, je rimski pesnik Lukrecij (De rerum natura, VI, 765), kar kaže, da se pisec Fiziologa, ki se sklicuje na neimenovanega naravoslovca, posredno ali neposredno navdihuje pri Pliniju, prvem naravoslovcu, ki piše, kako jeleni pobijajo kače. V Fiziologu je edini odklon od zgodbe, kakor jo navaja Plinij, v tem, da jelen kače ne izbeza s svojo sapo, temveč z vodo. Vzrok za spremembo (ki je pri antičnih avtorjih ne poznamo in je tudi velik del srednjeveških bestiarijev ne sprejme) je treba iskati v vsebinski zasnovi Fiziologa, ki poskuša ustvariti čim tesnejšo vez z biblijskimi motivi. Ker poglavje uvaja s podobo jelena, ki hrepeni po vodi življenja, je razumljivo, da je v zgodbi o preganjanju kač prav voda tista, s katero prežene kačo-hudiča. Sicer pa je alegorični komentar, ki sledi, dovolj poveden: »Človek, napolni svoja usta $z$ Božjo besedo po evangeliju, ki ti pravi, da ne kradi, ne ubijaj in ne prešuštvuj. In če najdeš v sebi kakšno zlo, ga izbljuvaj, pa boš pokončal kačo, iz katere izvira vsa nesreča, namreč Hudiča» (Fiziolog, 2001, 51-53).

V Fiziologu, pripisanemu sv. Epifaniju, najdemo zanimiv zapis, ki združuje Plinijevo različico, v kateri jelen izbeza kačo s svojo sapo, motiv vode pa je dodan na način, ki kar najbolj pripravno združuje antično vsebino z motivom iz dvainštiridesetega psalma. Anonimni pisec t. i. Epifanijevega Fizologa namreč pravi, da jelen potem, ko s svojo sapo izbeza in požre kačo, poišče izvir čiste vode in pije iz njega, da se reši pred zastrupitvijo. (Pisec dodaja celo natančen podatek, da mora jelen najti izvir $v$ treh urah, drugače umre. Nasprotno pa, če se pravočasno napije vode iz bistrega tolmuna, se prečisti in si življenje čudežno podaljša za naslednjih petdeset let.) V raz- 
lagi, ki sledi, kačo primerja $\mathrm{z}$ grehom in vodo $\mathrm{z}$ Božjo besedo, zapisano $\mathrm{v}$ Svetem pismu: „Pij iz izvira Božje milosti. In če se kesaš greha, ga bo voda v celoti izprala in boš povsem prenovljen " (Marino Ferro, 1996, 54).

Princip alegorične razlage lastnosti in vedenja živali, ki ga srečamo v Fiziologu, postavlja izhodišče za celoten srednjeveški razvoj živalske simbolike. Sam način alegorizacije je bil v poznohelenistični Aleksandriji zelo priljubljen, saj ga je v okviru biblijske eksegeze intenzivno razvijala zlasti aleksandrijska katehetska šola s Klementom Aleksandrijskim (ok. 150-215) in Origenom (ok. 185-254) na čelu. ${ }^{10}$ Vendar je Fiziolog prvo znano delo, ki je v celoti posvečeno razlagi simboličnih pomenov živali, delo, $v$ katerem so naravoslovna zapažanja premišljeno združena $\mathrm{z}$ biblijskimi vsebinami in skupaj z njimi interpretirana $v$ alegoričnem duhu. Nekateri od pionirjev v raziskovanju bestiarijev in Fiziologa ${ }^{11}$ so zagovarjali tezo, da je bil Fizio$\log$ sprva čisto naravoslovno delo brez moralnega komentarja, ki mu je bil domnevo dodan šele nekako v 4. ali 5. stoletju. To mnenje se je v strokovni literaturi nenavadno trdno zasidralo, kljub temu da je Friedrich Lauchert (Lauchert, 1889) z natančno primerjavo grških, latinskih, sirskih in etiopskih besedil Fiziologa dokazal, da je moraliziran komentar od vsega začetka integralni del besedila. Ron Baxter z zanimivo vsebinsko analizo dokazuje, da je moralni komentar celo ključni vsebinski dejavnik, saj je izbor in organizacijo poglavij mogoče razložiti le na podlagi alegoričnih pomenov živali, ne pa na temelju zoološke sistematizacije (Baxter, 1998). ${ }^{12}$

Stvarna opažanja o živalih so v Fiziologu skromna in zagotovo ne temeljijo na opazovanju, kar kaže, da avtorja ni zanimala resnična podoba živali in njihovih vedenjskih vzorcev, temveč njihova alegorična vloga. Naravoslovni podatki so povzeti iz različnih antičnih virov, pri čemer je izbor več kot očitno podrejen avtorjevi želji, da utemelji določen simbolični pomen

10 Za razvoj alegorične biblijske eksegeze glej zlasti Lubac, H. de, Exégèse Médiévale, Pariz, 1964.

11 Na primer Hommel, F., Die Aethiopische Uebersetzung des Physiologus, Leipzig, 1877.

12 Živali, ki nastopajo v Fiziologu, niso urejene po nobenem prepoznavnem zoološkem ključu, izbor in zaporedje sta povsem nepojasnljiva z vidika prirodoslovnih klasifikacij. V Fiziologu so sesalci pomešani s plazilci, ribami, pticami in insekti, udomačene živali z divjimi, eksotične vrste $\mathrm{z}$ domačimi vrstami itd. Hkrati pa poleg resnično obstoječih živali nastopajo mitska bitja, kot so sirene in kentavri, izmišljene živali kot feniks, kaladrij ali enorog, pravljično drevo Peridiksion in čudodelni ognjeni kamni. 
živali. V Fiziologu so namreč videz, vedenje in druge značilnosti živali pa tudi njihov nabor in zaporedje izpostavljeni v skladu z moralnim naukom, ki naj ga izražajo. Živali rabijo kot nosilci vlog, ki jim jih je avtor dodelil po v naprej določenem vsebinskem programu. Avtorjevo obravnavanje je dodatno potrjeno s tem, da različne živali igrajo isto vlogo in da se sorodni moralizirajoči vzorci ponavljajo s skupinami docela raznorodnih bitij resnične ali bajeslovne favne. Prav to je bistven preobrat v perspektivi zanimanja za živali, ki je zaznamoval nadaljnji razvoj ikonografije živali in obrodil bogate sadove v srednjem veku. ${ }^{13}$

Vprašanje, koliko je Plinijevo Naravoslovje vplivalo na pisca Fiziologa, je še vedno odprto, in večinoma je težko reči, ali se anonimni avtor v svojih razmeroma skopih naravoslovnih navedkih navdihuje neposredno pri Pliniju ali pri njegovih naslednikih. Marsikdaj se zdi verjetneje, da motiv, ki ga omenja Plinij, povzema po mlajših avtorjih, ki svoje znanje črpajo iz Plinija, vendar imajo več posluha za simbolično pomenljivost živali. Drugič spet kaže, da povzema iz starejše, fragmentarno ohranjene literature o čudesih sveta (in nenavadnih lastnostih živali) različnih avtorjev od psevdo Aristotela do Aleksandra iz Mindosa. ${ }^{14}$ Ker so se pri istih avtorjih navdihovali tudi že omenjeni Plinijevi nasledniki, je včasih nemogoče z zanesljivostjo razbrati poti vplivov. Bodisi da gre za neposredno bodisi za posredno povzemanje, je zanesljivo vsaj to: anonimni pisec je dobro poznal Naravoslovje in Plinijevega vpliva v Fiziologu ni mogoče spregledati. ${ }^{15}$ To pa še toliko bolj drži za bestiarije, ki so v visokem srednjem veku nasledili Fiziologa.

13 Obravnava živali kot nosilcev $v$ naprej določenih vlog z moralnim sporočilom je bila sicer že zdavnaj uveljavljena $\mathrm{v}$ grških basnih, vendar je zanimivo, da krščanska alegorična interpretacija dolgo zavrača antične basni kot vir za izoblikovanje simbolnih pomenov živali.

14 Fragmenti njihovih del so zbrani v t. i. paradoxographoi, ki jih je leta 1839 izdal Westermann, A., Paradoxographoi, scriptores rerum mirabilium Graeci, herausgegeben von A. Westermann, Branuschweig, 1839. Za vpliv tovrstnih spisov glej mdr. spremno študijo Otta Schönbergerja v: Physiologus Griechisch/Deutsch, Übersetzt und herausgegeben von Otto Schönberger, Stuttgart, 2001.

15 O Plinijevem vplivu $\mathrm{z}$ največjo zanesljivostjo govorimo v primerih, ko posamezne podatke ali različice navedb, ki jih omenja Fiziolog, prvič zasledimo v Naravoslovju. Tako na primer, motiv mladih lastovk, ki so pogosto slepe, a jih starši ozdravijo s krvavim mlečkom, ali motiv divjega osla, ki svojim potomcem odgrizne moda itd. 
Bestiariji, ki so se nekako v začetku 12. st. ${ }^{16}$ razvili neposredno iz latinskih prepisov Fiziologa, niso samo obsežnejši in vsebinsko bogatejši, temveč imajo tudi drugačno zasnovo. Opaziti je večji interes piscev za same živali, njihovo podobo in vedenjske značilnosti. Poglavja se množijo in v njih je včasih tudi do sto živalskih vrst urejenih po ustaljenem zaporedju, od leva kot kralja živali do manj odličnih plazilcev in rib, skoraj vse pa so opremljene $\mathrm{z}$ ustreznimi komentarji $\mathrm{v}$ duhu krščanske moralno-didaktične alegorike. Vidno je prizadevanje za vzpostavitev osnovne ureditve po načelih zoološke sistematike, originalna struktura Fiziologa razpade, živali so v grobem razdeljene v skupine štirinožcev, ptičev, kač in rib. V želji po natančnejšem poznavanju naravoslovnih dejstev so pisci bestiarjev veliko intenzivneje posegali po Plinijevem Naravoslovju in se velikokrat naravnost sklicevali na njegovo avtoriteto. Tudi kadar Plinij v bestiarijih ni neposredno naveden, so vsebine iz Naravoslovja bogato zastopane. Še pogosteje kot po samem Naravoslovju so povzete po Etimologijah Izidorja Seviljskega, ki pa svoje znanje o svetu živali najbolj dolguje prav Pliniju. ${ }^{17}$

Za ponazoritev si lahko ogledamo poglavje o jelenu, ki ga poznamo že iz Fiziologa. Anonimni pisec Bestiarija iz Oxforda, ${ }^{18}$ na začetku povzame navedek iz dvanajste knjige Izidorjevih Etimologij, s katerim pojasni izvor imena: »Obstaja žival, ki je zaradi svojih rogov imenovana jelen (lat. cervus, op. p.). Rogovom se namreč po grško reče cerata (Bestiarij iz Oxforda, 1988, 68). Nekoliko pozneje postreže s Plinijevo različico zgodbe o jelenih, ki s

16 Najzgodnejši ohranjeni primer je iz časa ok. 1120 in ga hranijo v Bodleian Library v Oxfordu (MS Laud. misc. 247). Po številu poglavij kakor tudi po vsebini je ta najstarejši bestiarij še zelo blizu Fiziologu.

17 Izidor Seviljski dvanajsto knjigo Etimologij (De animalibus) v celoti posveča živalim, pri čemer je njegov poglavitni vir prav Plinijevo Naravoslovje. Navezanost na Plinija je razvidna tudi v pristopu: čeprav Izidor (kot potrjuje omemba posameznih motivov, na primer, zgodbe o lovu na enoroga) nedvomno pozna Fiziologa, v svoje zapise o živalih ne vključuje Fiziologovih alegoričnih komentarjev, temveč poskuša biti čim bolj znanstveno objektiven in ohranjati naravoslovni pristop $\mathrm{z}$ dodatnim poudarkom na etimoloških razlagah živalskih imen. Glej mdr. James, M. R., The Bestiary, Oxford, 1928.

18 Bodleian Library, Oxford, Ms. Ashmole 1511. Bestiarij, ki je nastal ok. leta 1210, je dostopen tudi v faksimilni izdaji: Vollständige Faksimile-Ausgabe im Originalformat der Handschrift Ms. Ashmole 1511-Bestiarium, Gradec, 1988. Bestiarij iz Oxforda je lahko odločilen vzorec, saj pomeni zrelo različico t. i. druge družine bestiarijev, ki je bila najbolj razširjena in tako po vsebini kot po strukturi besedila dobro zastopa klasično obliko bestiarija (McCulloch, 1960). 
svojo sapo izbezajo kače iz njihovih lukenj. Hkrati v novem enciklopedičnem duhu pokaže svojo razgledanost in poznavanje snovi. Tako na kratko omeni, da imajo jeleni izjemno radi glasbo in da uživajo v poslušanju piščali. Čeprav se je prepričanje o ljubezni jelenov do glasbe v antiki zasidralo že z Aristotelom (Historia animalium, IX, 5) in ga poleg Plinija omenja tudi Plutarh (Moralia, 961E), je skoraj povsem zanesljivo, da pisec bestiarija sledi Pliniju. Na to kažeta jedrnatost trditve (Aristotel in Plutarh se s temo ukvarjata bolj na široko) in takojšnja povezava z motivom jelenjega sluha. Oba, Plinij in anonimni avtor bestiarija, namreč v naslednjem stavku spregovorita o »dejstvu«, da jelen z dvignjenimi uhlji odlično sliši, kadar pa jih povesi, je povsem gluh. Da gre resnično za povzemanje Plinija, je razvidno iz primerjave besedila. ${ }^{19} \mathrm{~A}$ še povednejše je dejstvo, da niti Opijan niti Ajlijan ali Solin ne omenjajo te posebnosti jelenjega sluha, medtem ko Aristotel navaja veliko bolj stvarno različico. $V$ njej pravi, da ima jelen $\mathrm{z}$ dvignjenimi uhlji izredno oster sluh in se mu ni mogoče približati, s povešenimi uhlji pa slabše sliši in ga lovci lahko presenetijo (Historia animalium, IX, 5). V prid tezi o naslonu na Plinija govori tudi dejstvo, da Izidor Seviljski s podobno jedrnatostjo in v enakem zaporedju opiše omenjene značilnosti, pri čemer njegova odvisnost od Plinija ni dvomljiva. ${ }^{20}$ Ker pisec Bestiarija iz Oxforda obenem navaja vsebine iz Naravoslovja, ki jih Izidor v svojem skrajšanem povzetku Plinija ne omenja, ni nobenega dvoma, da se navdihuje neposredno pri Pliniju, na katerega se v nekaterih drugih poglavjih tudi odkrito sklicuje. $^{21}$

Zgolj za ponazoritev dodajmo še primer, $v$ katerem je antična vsebina dopolnjena s srednjeveškim alegoričnim komentarjem. Gre za poseben način plavanja, ki jelenom omogoča varno prečkanje rek, jezer in celo morja.

19 "Kadar (jelen) dvigne uhlje, je njegov sluh izredno oster, kadar pa ima spuščene, ne sliši ničesar.« Bestiarij iz Oxforda, pogl. Jelen (navedeno po fr. izd. Philipa Lebauda, Le Bestiaire, Pariz 1988, 70). Prim. Plinijevo navedbo: »Njihov (jelenov) sluh je izredno oster, kadar dvignejo uhlje, kadar imajo spuščene, pa so gluhi« (Naturalis historia, 8, 50).

20 Glej mdr. Grant, R. M., Early Christians and Animals, London/New York, 1999, str. 114.

21 Tako na primer v poglavju o Pardu, Panterju, Risu, Bobru in številnih drugih. Seveda obstaja možnost, da so številne vsebine iz Plinijevega Naravoslovja navedene s posredovanjem Izidorjevih Etimologij, vendar primerjava besedil pa tudi pogosto sklicevanje na Plinija nasprotujeta misli, da je avtor Oxfordskega bestiarija Plinijevo delo poznal samo skozi Izidorjeve povzetke. 
V Bestiariju iz Oxforda beremo: „Če morajo jeleni prečkati velike reke ali prostrana morja, žival, ki plava od zadaj (za prvim jelenom, op. p.), nasloni svojo glavo na boke tiste, ki gre pred njo, in tako naprej do zadnje živali v čredi - na ta način se komaj kaj utrudijo« (Bestiarij iz Oxforda, 1988, 70). Plavanje v sklenjeni verigi, v kateri živali podpirajo druga drugo, omenja že Aristotel in ga po njem povzemajo Plinij, Ajlijan, Solin in Izidor Seviljski. ${ }^{22}$ Pisec bestiarija ga pospremi z naslednjimi besedami: »Analoški premislek $v$ tem samodejno prepozna povezavo s temi, ki pripadajo Sveti Cerkvi. Kadar kristjani zapuščajo svojo domovino, se pravi ta svet, zaradi ljubezni do nebeške domovine, pri tem podpirajo drug drugega - najpopolnejši pomagajo manj popolnim, da napredujejo zaradi njihovega zgleda in njihovih dobrih del. In če se jim na pot postavijo morja grehov, jih brez zadrževanja prečkajo « (Bestiarij iz Oxforda, 1988, 70). V poglavju o jelenu najdemo še nekaj vsebin, ki imajo jasno vzporednico v Plinijevem Naravoslovju, in enako velja za večino drugih poglavij, kar daje dovolj jasno sliko o vlogi Plinija v psevdoznanstveni in mistični zoologiji srednjega veka.

Če je vloga Plinijevega Naravoslovja pri oblikovanju simbolnih pomenov živali v pisnih virih dovolj jasna, je vprašanje vpliva v likovni umetnosti bistveno bolj problematično. S tem namreč trčimo ob zahtevno vprašanje ikonografske razlage živalske motivike v srednjeveški umetnosti, odnosa med obstoječimi pisnimi viri in likovno umetnostjo, ki smo ga nakazali že v uvodu. Kot rečeno, so stališča strokovnjakov različna, vendar obstajajo zanimivi indici, ki kažejo, da so pisni viri, v katerih se je izoblikovala živalska simbolika, hkrati temeljni in pogosto celo neposredni vir za ikonografijo živalskih podob v likovnih medijih. $\mathrm{V}$ več kot sto letih intenzivnih raziskav so umetnostni zgodovinarji opozorili na spomenike, pri katerih je vpliv bestiarijev nesporen. Gre za primere, ko se upodobitve zgledujejo po miniaturah $\mathrm{v}$ bestiarijih oziroma so ilustracije dobesedno prenesene $\mathrm{v}$ poljuben likovni medij ali pa je v spomeniku z živalsko motiviko mogoče prepoznati natančno določeno vsebino, ki izvira iz zapisov v bestiarijih. Čeprav se tovrstni »dokazi« množijo, ostajajo kljub vsemu nekako izolirani in ne morejo nesporno potrditi univerzalne vloge bestiarijev kot svojevr-

22 Prim. Plinij, Naturalis historia 8, 50; Ajlijan, De natura animalium V, 56; Opijan, De venatione II, 220-235; Solin, Collecteanea rerum memorabilium XIX, 11; Izidor Seviljski, Etymologiae XII, 1, 19. 
stnih ikonografskih priročnikov, s katerimi bi lahko pojasnili vsebino raznolike živalske motivike v srednjeveški umetnosti. Veliko pomembneje je, da poskusimo razumeti njihovo vlogo in pomen $\mathrm{v}$ srednjeveški kulturi ter osvetliti širok nabor možnosti njihovega vpliva na likovno umetnost.

Fiziolog in zgodnji bestiariji so najverjetneje bili moralno-didaktično berilo, namenjeno predvsem menihom, kar nakazuje donacija Filipa, kanonika Lincolnske katedrale, ki je podaril bestiarij avguštinskemu samostanu v Radefordu (zdaj Worksop), da služi »ad edificationem fratrem«. Takšno vlogo potrjujejo zapisi v posameznih bestiarijih, ki naravnost govorijo o vlogi tovrstnih knjig. Tako v Aberdeenskem bestiariju beremo, da je namenjen "za poboljšanje ljudi in boljše razumevanje, tako da bo duša vsaj zaznala stvari, ki jih težko dojamejo, da bodo to, kar težko razumejo z ušesi, opazili s svojimi očmi «. ${ }^{23}$ Moralno-didaktična in vzgojno-izobraževalna vloga je nenazadnje razvidna iz samega besedila Fiziologa, npr. iz poglavja o ognjenih kamnih, ki ga avtor sklene z nasvetom: »... zatorej se tudi vi, božji ljudje, ki živite to življenje, držite daleč od žensk, « (Baxter, 1998, 205) pa tudi iz celotne vsebinske zasnove Fiziologa, ki ima izrazito moralizirajočo noto. Kot $\mathrm{z}$ analizo jezika dokazuje Baxter, naj bi bil Fiziolog namenjen glasnemu branju v manjšem krogu poslušalcev, najverjetneje menihov ali samostanskih novicev. V besedilu, ki ima poudarjeno retorično dikcijo, so namreč pogoste literarne figure. (Anonimni avtor Fiziologa retorično ponavlja besede in besedne zveze na začetku stavka, piše v ritmično ponovljenih povedih, večkrat v variacijah ponovi isto vsebino, neposredno nagovarja bralca ipd.) Fiziolog naj bi imel torej neposredno moralno-didaktično funkcijo in naj bi bil vsaj v osnovi namenjen samostanskim skupnostim. ${ }^{24}$

V nasprotju s tem klasični bestiariji najverjetneje niso bili več namenjeni glasnemu branju, kar je razvidno tudi v jeziku, ki je bistveno bolj preprost, stvaren in manj govorniški. Neposredni moralno-didaktični poduk je navadno manj izrazit, precej bolj pa je izpostavljena njihova enciklopedična vrednost. Bestiarije bi lahko označili kot svojevrstne enciklopedije živalske alegorike, pri čemer je treba poudariti, da (psevdo)-znanstvena enciklope-

23 Prim. Bestiarij, Aberdeen MS 24, f. $25 v$ iz Aberdeen University Library v Aberdeenu.

24 To seveda ni edina vloga, saj so živalske prispodobe iz Fiziologa (kakor pozneje iz bestiarijev) uporabljali tudi kot exempla v pridigah, namenjenih širšemu občinstvu vernikov. 
dična vsebina in moralizirajoči alegorični komentar nista samo enakovredna, temveč neločljivo zraščena v celoto. V množenju poglavij, vključevanju novih živalskih vrst, v natančnejših opisih živali in njihovih vedenjskih značilnosti, ki jih spremlja ustrezno povečano število alegoričnih komentarjev, se vse jasneje izrisuje nova namembnost. Bestiariji pridobivajo vlogo enciklopedično zasnovane zbirke živalskih alegorij, ki rabi kot eden od priljubljenih virov pridigarskih exempla, ne pa kot samostojno vsebinsko zaokroženo čtivo, namenjeno javnemu branju. Eden ključnih dokazov za takšno vlogo bestiarijev v srednjeveški kulturi je pogostost navajanja živalskih prispodob v sočasnih pridigah. Thomas Welter je $\mathrm{z}$ izčrpno študijo L'exemplum dans la littérature religieuse et didactique du moyen âge (Welter, 1927) dokazal, da so prav bestiariji skupaj z življenji svetnikov poleg Biblije najpogostejši vir moralističnih zgledov, ki so jih uporabljali pisci pridig in govorov. Liber quo ordine sermo fieri debet, priljubljen srednjeveški priročnik za oblikovanje pridig Guiberta de Nogenta, med primernim materialom za exempla izrecno navaja biblične citate, cerkvene očete in "poučne zgodbe o kamnih, pticah, živalih, vse, ki o tem govorijo v prispodobah« (Welter, 1927, 35).

Posredno o vlogi bestiarijev govorijo tudi ohranjeni predmetni katalogi inventarjev samostanskih bibliotek in analize adligiranih kodeksov, $\mathrm{v}$ katerih se bestiariji pojavljajo kot sestavni del. Kataloški popisi razkrivajo, da so bestiariji sicer razporejali v zelo različne kategorije, da pa jih večinoma uvrščajo med teološka dela, in Baxter ob pregledu ohranjenih katalogov ugotavlja, da so bestiariji najpogosteje navedeni med moralističnimi teksti o krščanskih krepostih in pregrehah. Vzorec se še veliko bolj jasno izriše pri analizi kodeksov, v katerih so v enem zvezku vezana različna dela: bestiariji so daleč najpogosteje pridruženi besedilom o krepostih in pregrehah, pridigam in življenjem svetnikov. To ustvarja dovolj trdno sliko o prevladujoči vlogi bestiarijev kot vira za moralno-didaktične prispodobe pridigarjev. Baxter upravičeno opozarja tudi na dejstvo, da zlata doba bestiarijev sovpada $\mathrm{z}$ naglo širitvijo pridigarskih redov v 13. st., kar dodatno potrjuje prevladujočo vlogo teh »srednjeveških enciklopedij živalske alegorike» (Baxter, 1998, 183-209).

Ključ za razumevanje vplivnosti bestiarijev v likovni umetnosti se torej skriva v vlogi, ki so jo imeli v verskem življenju srednjeveškega človeka. V primerjavi s Fiziologom, ki je bil namenjen ožjemu krogu poslušalcev in je 
zato njegov vpliv bolj omejen, so bile moralistične živalske alegorije skozi pridige dostopne najširšim množicam vernikov. To pomeni, da so jim bile domače in njihov pomen dobro znan. $Z$ veliko zanesljivostjo lahko sklepamo, da so jim bile živalske podobe, ki krasijo zunanjščino in notranjščino srednjeveških cerkva, dovolj blizu, da so vsaj večinoma brez težav razumeli njihovo sporočilo. Upodobitve živali v sakralni umetnosti velikokrat dopolnjujejo biblijske motive, vsebine iz svetniških legend in najrazličnejših drugih religioznih tem, zato njihovega pomena nikakor ne smemo podcenjevati. Kakor večina sakralnih motivov imajo tudi podobe živali vlogo, da postavljajo verniku pred oči osnove krščanskega nauka in ga z jasnim moralnim podukom usmerjajo na poti, ki vodi v zveličanje. To je obenem najbolj smiselna razlaga, zakaj se podobe živali in živalskih alegorij tako pogosto javljajo v arhitekturnem okrasju cerkva, še posebej portalov. Podobno kot motiv Poslednje sodbe $\mathrm{v}$ timpanonih portalov romanskih in gotskih cerkva vernika opominja na potrebo po zglednem krščanskem življenju, tako tudi izbrani živalski motivi sporočajo isti nauk.

Vloga bestiarijev kot vira živalskih prispodob za pridige posredno govori tudi o vplivnosti Plinijevega Naravoslovja, ki je v bestiarijih veliko bolj prisotno kot v Fiziologu. Pri tem ne smemo spregledati dejstva, da so bestiariji resda izredno pomemben, vendar nikakor ne edini vir za srednjeveško ikonografijo živali. Opazen je namreč vpliv srednjeveške enciklopedike, ki je od Izidorjevih Etimologij do velikanskega kompendija Speculum majus Vincenca iz Beauvaisa (1190-1265) tvorno sooblikovala različne segmente krščanskega naravoslovja in posledično ikonografijo živali. Skoraj odveč je ponavljati, da so vsi vodilni pisci enciklopedij do 13. st. navajali ali povzemali Plinija kot najvišjo avtoriteto na področju naravoslovnih znanosti in da tudi pozneje, ko ga je s piedestala izrinil Aristotel, Plinijevo delo ni izgubilo nekdanje veljave. Naravoslovje je bilo torej izobraženim naročnikom srednjeveške umetnosti dobro znano bodisi neposredno bodisi posredno, široke množice pa so se $\mathrm{z}$ drobci Plinijevega dela seznanjale po ovinkasti poti živalskih podob, ki so jih pridigarji črpali iz bestiarijev.

Pri iskanju odgovorov na vprašanja o vplivnosti klasičnih virov na krščansko ikonografijo živali nam lahko nekoliko pomaga pogled v renesančno kulturo in umetnost. Razvoj renesančnega humanizma s ponovnim odkrivanjem in kritičnim vrednotenjem antične dediščine je prinesel velik 
napredek v poznavanju izvirnih besedil in omogočil bistveno boljše razumevanje civilizacijskih dosežkov grško-rimskega sveta. Nov, bolj kritičen odnos se je vzpostavil tudi v naravoslovju in renesančniki niso prizanesli niti Pliniju, ki je skozi ves srednji vek veljal za nesporno avtoriteto. Leta 1492 je Niccolo Leonceno v svoji knjigi De erroribus Plinii ostro kritiziral napake in pomanjkljivosti Plinijevega Naravoslovja, ki je v novoveški znanosti izgubilo svoj prestižni položaj. ${ }^{25}$ Toda pospešen razvoj naravoslovnih znanosti ni zavrl zanimanja za simbolično pomenljivost živali v likovni umetnosti in na tem področju je Plinijev ugled (nekoliko paradoksalno) ostal nedotaknjen.

V renesansi ni težko najti neposrednih dokazov za prenos plinijevskih vsebin v likovno umetnost. Vpliv Naravoslovja je posebej lepo razviden pri Leonardu, ki je, kot pravi »uomo universale« spisal tudi svoj mali »bestiarij«. ${ }^{26} \mathrm{~V}$ njem najdemo večino živali, ki jih omenjajo že srednjeveški bestiariji, v svojih zapisih pa se Leonardo vidno opira prav na Plinija. Z vidika sledljivosti vpliva Naravoslovja je zanimivo, da Leonardo, ki velik del svojih opisov povzema po Pliniju, njegovega imena v zvezi z živalmi ne navaja. ${ }^{27}$

Čeprav ima Leonardov »bestiarij« neenotno strukturo in so v njem tudi poglavja brez alegoričnega komentarja, je simbolična vrednost živali povsem nedvoumna, saj so iste živalske vrste obravnavane v različnih poglavjih in imajo vsaj v enem od njih tudi metaforično razlago pomena. Tako na primer najdemo za kamelo dva zapisa. V prvem nas Leonardo (kot skoraj

25 Prim. Sarton, G., The Appreciation of Ancient and Medieval Science during the Renaissance (1450-1600), University of Pennsylvania Press, 1995.

26 Leonardove zapise o živalih, ki so se kot sklenjen spis ohranili v kodeksu H (fol. $5^{\mathrm{r}-} 27^{\mathrm{v}}$ ), lahko le pogojno imenujemo bestiarij, saj nimajo enake zasnove kot srednjeveški bestiariji in so izrazito oseben izraz Leonardovega zanimanja za svet živali in njihovih simbolnih pomenov.

27 Leonardo navaja Plinijevo Naravoslovje v zvezi z različnimi temami, na primer ob vprašanju slanosti morja, konstrukciji katapulta ali iznajdbi meča, medtem ko ga v svojem »bestiariju« ne omenja. Prim. Leonardo da Vinci, Tagebücher und Aufzeichnungen, prev. Lücke, T., Leipzig, 1940. Za vpliv Plinija na Leonardov »bestiarij« glej mdr.: Leonardo da Vinci, Frammenti litterari e filosofici, izd. Solmi, E., Firence, 1979, str. 290-291. Solmi opozarja, da je Pietro Landino leta 1476 Plinijevo Naravoslovje prevedel v italijanščino, s čimer se je njegov vpliv še okrepil. Za možne srednjeveške ilustrirane vire, pri katerih naj bi se navdihoval Leonardo glej: Cogliati Arano, L., Fonti figurative del »Bestiario« di Leonardo, Arte Lombarda 62 (1982), str. 151-160. 
tisočletje in pol pred njim Plinij) pouči o tem, da imajo baktrijske kamele dve grbi, arabske pa imajo samo eno. Sledi tradicionalno opozorilo na njihovo vzdržljivost in občutek za mero - če jo trgovci pretirano otovorijo, se ne bo premaknila, prav tako pa v enem dnevu ne bo opravila več poti, kakor je navajena (Leonardo da Vinci, 1979, 66) ${ }^{28} \mathrm{~V}$ drugem zapisu srečamo kamelo pod naslovom Zmernost, kjer ponazarja občutek za mero, obvladanost in zmernost. Posamezna poglavja »bestiarija« se namreč ne začenjajo $s$ predstavitvijo živali, temveč z navedbo različnih moralnih vrlin ali slabosti, idej in pojmov, v katerih so živali izključno za ponazoritev izbrane ideje. "Kamela je po naravi najbolj pohotna žival, kar jih je, " piše Leonardo v poglavju o zmernosti, »in samec je pripravljen teči tisoč milj, da ujame samico. Toda svoje matere ali sestre se ne bo nikoli dotaknil, tako dobro se zna obvladati« (Leonardo da Vinci, 1979, 56). Nekateri drugi zapisi še bolj sumarno izražajo simbolični pomen živali. Tako na primer krokodila že v naslovu opredeli kot simbol hinavščine (Leonardo da Vinci, 1979, 61), o močeradu pa pravi: »Močerad si v ognju oplemeniti svojo kožo - pomeni krepost ..." (Leonardo da Vinci, 1979, 59). Izvirni zapis v italijanščini je z ikonološkega vidika še posebej zanimiv, saj izraža vsebinsko noto, ki jo je v slovenskem prevodu skoraj nemogoče ohraniti. Leonardo namreč pravi: »La salamandra nel foco raffina la sua scorza. Per la virtu. $S$ takšnim poudarkom je, kakor opozarja že Theodor Lücke, dejansko implicirana funkcija zapisa kot slikarjeva zabeležka, kako uporabiti močerada kot nosilca simbolnega pomena (Lücke, 1940, 841).

Leonardovo prenašanje na Pliniju in na bestiarijih temelječe simbolike živali v likovno umetnost kaže, da je renesansa prevzela temeljna načela živalske alegorike, kakor jo je razvil srednji vek. Nobenega dvoma ni, da so podobno razmišljali tudi drugi umetniki (in naročniki), saj v renesančni umetnosti ne manjka živalskih podob, ki imajo dovolj jasno berljivo simboliko. Dokončno standardizacijo simbolnega razumevanja živali v likovni umetnosti pa pomeni uveljavitev emblemskih knjig in ikonografskih priročnikov, v katerih imajo živali natančno določen simbolni pomen.

Najvplivnejši tovrstni priročnik je Ikonologija (Iconologia), ki jo je spisal široko izobraženi italijanski humanist Cesare Ripa. Delo je leta 1593 izšlo

28 Primerjaj zapis v Naravoslovju $(8,26)$. 
v Rimu, šest let pozneje je bila natisnjena prva ilustrirana izdaja, sledila je vrsta ponatisov in prevodov. ${ }^{29}$ Ripa je znanje črpal iz antičnih del ter srednjeveških enciklopedij in priročnikov, ki jih je dopolnil s sodobnim poznavanjem mitologije, zgodovine, leposlovja, naravoslovja in seveda likovne umetnosti. Hkrati se je močno opiral na renesančno hieroglifiko in emblematiko, ki sta izrednega pomena za razvoj živalske simbolike v novem veku. ${ }^{30} \mathrm{~S}$ sistematičnim delom je ustvaril enoten tip personifikacij, oblikovan po jasnih načelih graditve alegoričnih likov, ki vključuje tudi živali in razlago njihovih pomenov. V slednjem se nemalokrat sklicuje na Plinija. ${ }^{31}$ Tako Slon - »najpobožnejša žival in simbol vernosti«- po mnenju Ripe pripada personifikaciji Vernosti (Religio), kajti: »Plinij na že omenjenem mestu pravi, da slon časti sonce in zvezde, a kadar nastopi mlada luna, se spontano

29 Cesare Ripa, Iconologia overo Discrittione d'Imagini delle Virtù, Vitii, Affetti, Passioni humane, Corpi celesti, Mondo e sue parti..., Rim, 1593. Med poznejšimi je posebno priljubljena ilustrirana padovanska izdaja iz leta 1611.

30 Renesančna hieroglifika se je razvila v Italiji pod vplivom poznoantičnega spisa Hieroglifika (Hieroglyphica), ki ga je leta 1419 na grškem otoku Androsu odkril florentinski duhovnik Christoforo de' Buondelmonti. Prevod knjige, ki naj bi bila po besedah avtorja (znanega le s psevdonimom Horapollo Niliacus) ključ za razumevanje svete egipčanske pisave, je v krogih italijanskih humanistov požel izreden uspeh, saj so se renesančni humanisti živo zanimali tako za staro modrost Egipčanov kakor za izoblikovanje pisave vizualnih simbolov, ki bi bila razumljiva le ozkemu krogu izobražencev. Horapolonova Hieroglifika je nastala v času poznega helenizma, najverjetneje $\mathrm{v} 4$. stoletju našega štetja, in je zgrešen poskus razbiranja egipčanske slikovne pisave. Horapolon predpostavlja, da so hieroglifi oblikovani po načelu premišljenega nizanja simbolnih podob, katerih seštevek oblikuje skrito sporočilo. Razumevanje hieroglifske pisave naj bi bilo torej odvisno od uspešnega tolmačenja simbolov, ki jo sestavljajo. Navdušenje nad »odkritjem« se je kmalu pokazalo v razmahu renesančnih hieroglifov in najpomembnejše delo s tega področja je obsežna Hieroglifika Giovannija Pieria Valeriana, izdana v Baslu leta 1556 (Hieroglyphica sive de sacris Aegyptiorum aliarumque gentium literis). Valerianovo delo je velik »besednjak hieroglifov«, in ker je med njimi mnogo živalskih podob, je opazno zaznamovalo tudi nadaljnji razvoj ikonografije živali. Renesančna emblematika je podobno kot hieroglifika značilen izraz humanistične ljubezni do govorice simbolov. Renesančni emblem je likovno/literarna oblika, ki s kombinacijo slikovnega in besednega dela ponazarja izbrano vsebino ter največkrat rabi za izražanje moralnih naukov ali idejnih podukov. Za očeta renesančnega emblema velja italijanski humanist Andrea Alciati (1492-1550) s Knjigo emblemov (Emblematum Liber), ki je leta 1531 izšla v Augsburgu. Knjiga je bila prava uspešnica in razširjena izdaja iz leta 1550 je bila velikokrat ponatisnjena ter prevedena $\mathrm{v}$ številne evropske jezike, Alciatijevemu vzoru pa so kmalu sledili francoski, nemški, španski in nizozemski pisci s svojimi knjigami emblemov. Glej: Henkel, A. in Schöne, A. (izd.), Emblemata, Handbuch zur Sinnbildkunst des 16. und 17. Jahrhunderts, Stuttgart, 1976.

31 Ripa se v Ikonologiji na Plinija neposredno sklicuje več kot štiridesetkrat! 
odpravi $k$ reki, da se umije, in kadar zboli, prosi za ozdravitev in pomoč $z$ neba, tako da meče travo $v$ zrak «. ${ }^{32}$ Včasih Ripa simbolne pomene živali utemeljuje celo z zmotnim sklicevanjem na Plinija, s čimer ustvarja paradoks plinijevske ikonografije, ki s samim Plinijem v resnici nima nobene zveze. V opisu poosebitve Darežljivosti (Liberalità), na primer, med drugim pravi, da mora imeti figura orlovski nos in nad glavo upodobljenega orla, ker je orel najbolj darežljiva od vseh ptic. Orla kot podobo Darežljivosti takole utemelji: "Plinij piše, da kadar orel s svojim trudom upleni kako žival, ne gleda samo na to, kako bo potešil svojo lakoto, temveč nikoli ne pozabi pustiti del plena drugim pticam ... «33 Ripov zapis lahko razumemo kot pomoto, ki pa je sama po sebi dovolj indikativna. Kaže namreč, da je Ripa Plinijevo Naravoslovje uporabljal tudi »na pamet«, da mu je bilo samoumevna referenca in da ni dosledno preverjal podatkov, za katere je bil prepričan, da jih pozna iz dela največjega rimskega naravoslovca.

Izrednega pomena za razumevanje kompleksnega vprašanja plinijevskih vsebin v Ikonologiji in v celotni renesančni ikonografiji je dejstvo, da se Ripa pri oblikovanju svojih personifikacij močno naslanja tudi na uveljavljeno likovno tradicijo poznega srednjega veka. Orla kot simbol darežljivosti namreč najdemo že pri Pisanellu. Bronasta medalja, ki jo je Pisanello leta 1449 izdelal za kralja Alfonza Aragonskega, ima na hrbtni strani orla, ki ponosno stoji nad uplenjeno srno. Ob njem so upodobljene manjše ujede, ki čakajo, da jim orel prepusti del svojega plena, napis LIBERALITAS AUGUSTA pa nedvoumno sporoča, da gre za simbol vladarske darežljivosti. ${ }^{34}$ Ripa torej zajema tudi iz likovnega besednjaka uveljavljenih živalskih

32 "...racontando pur esso Plinio al luogo citato, che egli ha in veneratione il Sole, \& le Stelle, \& apparendo la nouva Luna, spontaneamente va a lavar si in acqua di vivo fiume, \& amalandosi chiama aiuto dal Cielo, buttando verso il cielo dell'herbe, come mezi, per intercedere gratia di sanità» (Ripa, 1611, 457). Prim. Plinij, Naturalis historia $(8,1)$.

33 »Scrive Plinio, che l'aquila se fà preda di qualche animale per propria industria, non attende tanto satiare l'appetito suo, che non si ricordi sempre di laficiarne parte à gl'altri vccelli ..." (Ripa, 1611,311). Plinij v poglavju o orlu ne navaja nič temu podobnega. Prim. Naturalis historia (10, 3-6).

34 Glej: Puppi, L. (ured.), Pisanello. Una poetica dell'inatteso, Milano, 1996, str. 177-183. Primerjaj tudi: Cordellier, D. (ured.), Pisanello. Le peintre aux sept vertus (katalog razstave v Louvru 6. 5. - 5. 8. 1996), Pariz, 1996, str. 435. Na Pisanellovih bronastih medaljah pogosto najdemo podobe živali z nesporno simbolno vrednostjo, ki kažejo, da so bile avtorju poleg živalskih motivov iz srednjeveške heraldike znane tudi vsebine, ki izvirajo neposredno iz bestiarijev. 
simbolov, pri čemer je njegovo (včasih zmotno) sklicevanje na Naravoslovje zelo ilustrativno: opozarja namreč na pomen, ki ga je renesančni učenjak pripisoval vplivu Plinija na srednjeveško simboliko živali.

Neposrednega vpliva Plinijevega Naravoslovja na ikonografijo živali v evropski umetnosti, ki je v renesansi (in v poznejših obdobjih) izpričan $\mathrm{z}$ deli, kot so Ripova Ikonologija in emblemske knjige, v srednjem veku ni mogoče dokazati z enako zanesljivostjo. Ikonografskih priročnikov, ki bi bili namenjeni umetnikom (in ljubiteljem umetnosti ter naročnikom), $\mathrm{v}$ srednjem veku ne zasledimo. Prav tako ne poznamo zapisov kakega srednjeveškega umetnika, ki bi kakor Leonardove zapiske v njegovem »bestiariju « nedvoumno potrjevali zavestno uporabo živalske simbolike v likovni umetnosti. Iskanje tovrstnih »nespornih dokazov« je v naprej obsojeno na neuspeh, saj srednjeveški umetniki navadno niso bili hkrati snovalci ikonografskih programov in se svojih del niso lotevali na enak način kot Leonardo da Vinci. A tudi srednji vek premore umetnika Leonardovega kova. Vsestransko nadarjeni francoski mojster Villard de Honnecourt v zgodovini umetnosti velja za srednjeveškega predhodnika Leonarda da Vincija, za nas pa je izjemno pomembna njegova Skicirka. ${ }^{35}$

V fragmentarno ohranjeni Skicirki, v katero si je Villard de Honnecourt nekako med letoma 1225-1235 skiciral načrte cerkva, narise pročelij, najrazličnejše arhitekturne detajle, ideje za cerkveno opremo, kiparski okras, izvirne mehanične naprave ipd., najdemo tudi obilico živalskih študij. Villardovo zanimanje za živali je vsestransko - zanimata ga tako resnični videz kakor tudi shematično konstruirana podoba, ki jo mojster gradi na osnovi geometrijskih likov. (Namen shematičnih upodobitev je oblikovanje idealnega prototipa ali vzorca, ki ga je mogoče uporabiti v različnih likovnih medijih.) Najlepši in najznamenitejši primer je zagotovo risba leva, ki je po eni strani izredno naturalistična (Villard se $\mathrm{z}$ napisom ob risbi pohvali, da je narejena $» a l$ vif«, po naravi torej), hkrati pa je princip idealizirane gradnje $\mathrm{z}$ uporabo geometrijskih likov več kot očiten. ${ }^{36} \mathrm{Kljub}$ temu da

35 Za Skicirko Villarda d'Honnecourta glej zlasti klasično monografsko predstavitev: Hahnloser, H. R., Villard de Honnecourt. Kritische Gesamtausgabe des Bauhüttenbuches ms. fr. 19093 der Pariser Nationalbibliothek, Gradec, 1972.

36 Tradicionalno razumevanje Villardovega zapisa »contrefais al vif« (»narejen po živem modelu« ali »narejen po naravi«) lahko sicer razlagamo tudi drugače, namreč da gre za študijo, 
je Villard skiciral (tudi) žive živali, je iz posameznih živalskih kompozicij razvidno, da je bodisi prerisoval miniature iz bestiarijev bodisi so mu bile slednje tako domače, da je kompozicijske rešitve iz bestiarijev samodejno prenašal v svoje risbe. To kaže, da je dobro poznal bestiarije in torej tudi simbolne pomene živali, ki so v njih navedeni. ${ }^{37}$ Kot ugotavlja Hahnloser, je risba laboda ${ }^{38} \mathrm{z}$ značilno dvignjenimi perutmi povzeta po bestiarijih. Villard je poudaril moč peruti, ki jih razdražen labod dvigne, kadar se mu bliža sovražnik - značilnost, o kateri govorijo tako antični kot srednjeveški naravoslovci. Še zanimivejša je podoba bobra, ${ }^{39}$ saj kaže, da Villard bobra nikoli ni videl v živo. Po drugi strani pa risba nenavadne zveri, ki si poskuša odgrizniti lastna moda, več kot očitno sledi uveljavljenemu tipu upodabljanja bobra v bestiarijih. Bestiariji namreč kot bistveno značilnost bobra omenjajo, da si žival, ki jo lovci lovijo zaradi zdravilne vrednosti mod, v nevarnosti sama odgrizne del telesa, zaradi katerega jo preganjajo. Kot zanimivost omenimo, da »dejstvo « med antičnimi naravoslovci prvi omenja prav Plinij v svojem zapisu o bobru (Naturalis historia, 8, 47). ${ }^{40}$ Ključen dokaz, da je Villard dobro poznal simbolne pomene živali, kakor so jih izoblikovali bestiariji, ponujajo risbe, kjer jukstapozicija dveh živali temelji na njuni simbolični pomenljivosti. Tak primer je študija pelikana in sove na prvem foliju Skicirke. ${ }^{41}$ Hahnhloser ne dvomi, da gre za tradicionalno ikonografijo, ki izvira iz bestiarijev: pelikan simbolizira Kristusa, njegovo

narejeno neposredno po modelu, in ne po naravi (Perrig, 1991, 105-121). To je pri levu tudi veliko bolj verjetno, vendar natančne študije živali v Villardovi Skicirki ne puščajo nobenega dvoma, da je pozorno opazoval živali in jih risal tudi po naravi.

37 Xenia Muratova zagovarja tezo, da je Villard velik del študij živali prerisal iz angleških bestiarijev poznega 12. st. (Muratova, 1985, 1319-1362).

38 Skicirka, fol. 4r (Hahnloser, 1972, sl. 7).

39 Skicirka, fol. 7v (Hahnloser, 1972, sl. 14). Hahnloser stilizirano žival interpretira kot psa. Da je njegova razlaga najbrž napačna, razkriva primerjava s tremi risbami psov, ki jih najdemo v Villardovi Skicirki (fol. 18v, fol. 24r in fol. 26r), kjer je fiziognomija pasje glave in telesa povsem nesporna, risba na fol. 7 pa kaže, da mojster ni imel v mislih psa, temveč podobo bobra, kakor jo je imel priliko videti v ilustriranih bestiarijih. V njih je bober nekoliko podoben psu, vendar ga prepoznamo po nezgrešljivi drži, kako tišči glavo med zadnje noge in si poskuša odgrizniti moda.

40 Aristotel in naravoslovci pred Plinijem te zanimivosti ne navajajo, po Pliniju pa jo povzemajo tako Fiziolog kakor tudi Ajlijan, Izidor Seviljski in pisci bestiarijev. Bobra, ki si odgrizne moda, omenjata tudi Ezop v svojih basnih in Cicero v Nagovoru Skavru.

41 Skicirka, fol. 1r. Prim. Hahnloser (1972), sl. 1. 
žrtev, krščansko ljubezen in vero v vstajenje, sova pa pomeni židovstvo oz. krivoverstvo, ki ne sprejema Kristusove žrtve in živi v temi, brez luči prave vere in brez upanja v odrešitev (Hahnloser, 1972, 5-6 in 269-272).

Pomen Skicirke Villarda de Honnecourta je v okviru raziskovanja vplivnosti literarnih virov na ikonografijo upodabljajoče umetnosti skorajda enakovreden zapisom Leonarda da Vincija. Oba namreč črpata iz istih literarnih virov, oba sprejemata simbolično pomenljivost živali in oba jo neposredno prenašata v likovni medij. Rekli bi lahko, da je Villardova Skicirka celo pomembnejša od Leonardovega »bestiarija «. Gre namreč za knjigo vzorcev (Musterbuch), ki je rabila kot priročnik, s katerim si umetnik pomaga naslikati oziroma izklesati podobe tako, da bosta njihov videz in pomen zadovoljila estetske in vsebinske zahteve naročnika. ${ }^{42}$ Hahnloser Villardovo Skicirko označi kot Summa scientiae et artis (Hahnloser, 1972, 238 ) in natančno opredeli njeno vlogo z vidika srednjeveške knjige vzorcev, hkrati pa upravičeno zapiše, da risbe živali nikakor niso naključne. Vsaka od njih služi svojemu namenu in ima natančno določen pomen. Množica risb živali v Skicirki odseva naraščajoče zanimanje za živalski svet, o čemer priča razcvet bestiarijev in tudi bolj naravoslovno usmerjenih knjig o živalih, kot sta Liber de natura rerum Thomasa de Cantipré ali De animalibus libri XXVI Alberta Velikega na eni ter gotsko »odkritje narave« v likovni umetnosti na drugi strani. ${ }^{43}$ Prva polovica 13. st. je hkrati čas, ko ugled Plinijevega Naravoslovja doseže svoj zenit. Je bilo njegovo delo dovolj znano, da so ga poznali tudi umetniki kot Villard de Honnecourt?

42 Za Villardovo Skicirko kot srednjeveško knjigo vzorcev in možne druge interpretacije glej: Scheller, R. W., Exemplum. Model-Book Drawings and the Practice of Artistic Transmission in the Middle Ages (ca. 900-1450), Amsterdam, 1995, str. 176-187.

43 Mogoče ni odveč spomniti, da sta tako Thomas de Cantipré (ok. 1200 -1274) kot Albert Veliki (ok. 1193-1280) sodobnika Villarda de Honnecourta. O naraščajočem zanimanju umetnikov za naravo in neposrednem vplivu Fiziologa ter bestiarijev pa pričajo tudi ostanki nekaterih drugih srednjeveških »knjig vzorcev«, na primer t. i. Reiner Musterbuch iz cistercijanskega samostana Rein blizu Gradca. Rokopis, v katerem so prerisi živali iz Fiziologa s spremnim besedilom (!), je nastal v letih 1208-1218 in je torej le malo starejši od Villardove Skicirke. Prim. Reiner Musterbuch, Faksimile-Ausgabe im Originalformat des Musterbuches aus Codex Vindobonensis 507 der Österreichischen Nationalbibliothek, Kommentar Franz Unterkircher, 2 vols., Gradec 1979, in R. W. Scheller, Exemplum. Model-Book Drawings and the Practice of Artistic Transmission in the Middle Ages (ca. 900-1450), Amsterdam 1995, str. 149-154. 
Mogoče nam delček odgovora na to vprašanje razkrije Villardova risba ježevca, na fol. $24 \mathrm{v}$. ob kateri je pripis: »Ves ci i porc espi; c'est une biestelete $q(u) i$ lance se soie, quant ele (est) corecie« ${ }^{44} \mathrm{O}$ posebnosti ježevca, ki izstreli svoje bodice, se je Villard lahko poučil v različnih virih, ki jih v svojem zapisu o ježevcu zvesto navaja njegov sodobnik Vincenc iz Beauvaisa (De Natura Animalium, I, 31). O sposobnosti ježevca, da svoje bodice izstreli kot puščice, najobširneje piše Opijan, ki ga primerja z izkušenim lokostrelcem (Kynegetica, III, 392). Tudi Ajlijan verjame v nenavadno sposobnost te živali (De Natura Animalium, I, 31). Z vidika vplivnosti Naravoslovja je zanimivo, da ježevca, ki izstreli bodice, prvi omenja prav Plinij, ki pravi: »Bodice ježevca so daljše (od ježevih) in se postavijo pokonci, kadar napne kožo: $z$ njimi zbode pasje gobce, ki grabijo po njem, in jih uporabi kot izstrelke, kadar so bolj oddaljeni« (Naturalis historia, 8, 53). Res je, da ježevca, ki se brani z bodicami, omenja že Aristotel. Vendar Aristotel zgolj zapiše, da žival svoje bodice »uporablja kot orožje« proti sovražnikom (Historia animalium, IX, 623a). Primer ježevca je posebno zanimiv, saj lepo ponazarja, kako so se razvijale vsebine, iz katerih so izšli simbolni pomeni živali. Aristotelov stvarni, vendar metaforično obarvan opis je Plinij svobodno stopnjeval in tako ustvaril podobo ježevca, ki lahko (dobesedno) izstreli svoje bodice. Predstava, ki so jo po njem povzeli pisci bestiarijev, je v srednjem veku botrovala izoblikovanju simbolnih pomenov, ki jih razbiramo tudi v likovni umetnosti. Zaradi njih si je ježevca, o katerem Plinij pravi, da se uspešno brani pred bližnjimi in daljnimi sovražniki, francoski kralj Ludvik XII. izbral za svojo grbovno žival. ${ }^{45}$

Gre torej za ikonografijo, ki se je nesporno izoblikovala pod vplivom Plinijevega Naravoslovja. Skicirka Villarda de Honnecourta je, kolikor mi je znano, edini primer, da srednjeveški umetnik ob študiji živali zapiše opazko, ki izvira iz Naravoslovja. Želja umetnostnih zgodovinarjev, da bi našli čim več podobnih nedvoumnih pričevanj, je razumljiva, a v svojem bistvu zgrešena, saj ne upošteva temeljnih zakonitosti umetniške produkcije v sre-

44 »To je ježevec, zverinica, ki izstreli svoje bodice, kadar je razdražena« (Hahnloser, 1972, 149).

45 Ludvik XII. (1462-1515) je ježevca $\mathrm{z}$ motom »Cominus et eminus« vzel za svoje heraldično znamenje, saj je hotel s tem povedati, da bo tolkel svoje sovražnike od blizu in daleč. Ježevec je $\mathrm{v}$ takšnem pomenu uveljavljen tudi v renesančni emblematiki in v knjigah impres. Glej mdr. Scipione Bargagli, La prima Parte dell'Imprese, Siena, 1589, str. 44; ali Joachim Camerarius, Symbolorum et emblematum..., Nürnberg, 1605, vol. II, embl. št. 125. 
dnjem veku. Srednjeveški slikarji in kiparji skoraj zanesljivo niso brali Plinija. In najbrž so redki tisti, ki so sami prebirali bestiarije, da bi se poučili o simboliki živali. Delali so po naročilu in ikonografski program so vsaj v spomenikih sakralne umetnosti določali (bolj ali manj) izobraženi kleriki. Ti pa so, kot izhaja iz analize vloge bestiarijev v srednjem veku, plinijevske vsebine vsaj posredno poznali in jih s pridom uporabljali v moralno-didaktične namene. $\mathrm{V}$ pisani in govorjeni besedi, s pomočjo kiparjev in slikarjev pa tudi v likovni umetnosti.

\section{VIRI}

Ajlijan, Perí zóion idiótetos (De natura animalium), mdr. dostopno v The Loeb Classical Library z angl. prev. A. F. Scholfielda, On the Characteristics of Animals, 3 vol., Cambridge, Mass., 1958-59.

Aristotel, Tón perí tá zóia istoríon (Historia animalium) z angl. prev. A. L. Pecka, History of Animals, Cambridge, Mass., 1965.

Scipione Bargagli, La prima Parte dell'Imprese, Siena, 1589.

Joachim Camerarius, Symbolorum et emblematum..., Nürnberg, 1605.

Bestiarij iz Oxforda, Vollständige Faksimile-Ausgabe im Originalformat der Handschrift Ms. Ashmole 1511-Bestiarium, Gradec, 1988.

Fizolog, Physiologus Griechisch/Deutsch, Übersetzt und herausgegeben von Otto Schönberger, Stuttgart, 2001.

Fizolog, Physiologus Bernensis, voll-Faksimile Ausgabe des Codex Bongarsianus 318 der Burgerbibliothek Bern, izd. Ch. Steiger, Basel, 1964.

Izidor Seviljski, Isidori Hispalensis Episcopi Ethymologiarum sive Originum libri XX, izd.W. M. Lindsay, 2 vol., Oxford, 1966.

Leonardo da Vinci, Frammenti litterari e filosofici, izd. E. Solmi, Firence, 1979.

Opijan, Kynegetkón, Halieutikón, mdr. dostopno v The Loeb Classical Library z angl. prev. A. W. Maira, Cynegetica or The Chase, Halieutica or Fishing, Cambridge, Mass., 1958. 
Plinij starejši, Naturalis historia libri XXXVII, z angl. prev. H. Rackhama, Natural History, 10 vol., Cambridge, Mass., 1947.

Plutarh, De sollertia animalium, v: Moralia, z angl. prev. F. C. Babbitta idr., Plutarch's Moralia, 15 vol., Cambridge, Mass., 1969.

Solin, Collectanea rerum memorabilium, izd. Th. Mommsen, Berlin, 1895.

\section{LITERATURA}

Allen, J. R., Early Christian Symbolism in Great Britain and Ireland before Thirteenth Century, London, 1887.

Baxter, R., Bestiaries and their Users in the Middle Ages, London, 1998.

Benton, J. R., Bestiaire médiéval. Les animaux dans l'art du Moyen Âge, New York/Pariz/Abbeville, 1992.

Berlioz, J. in Polo de Beaulieu, M. A. (ur.), Lanimal exemplaire au Moyen $\hat{A} g e$ ( $V^{e}-X V^{e}$ siècles), Rennes, 1999.

Bianciotto, G., Bestiaries du Moyen Age, Pariz, 1980.

Clark, W. B. in McMunn, M. T. (izd.), Beasts and Birds of Middle Ages, The Bestiary and Its Legacy, Philadelphia, 1989.

Cogliati Arano, L., Fonti figurative del "Bestiario" di Leonardo, Arte Lombarda 62 (1982), str. 151-160.

Cordellier, D. (ured.), Pisanello. Le peintre aux sept vertus (katalog razstave v Louvru 6. 5. - 5. 8. 1996), Pariz, 1996.

Grant, R. M., Early Christians and Animals, London/New York, 1999.

Hahnloser, H. R., Villard de Honnecourt. Kritische Gesamtausgabe des Bauhüttenbuches ms. fr. 19093 der Pariser Nationalbibliothek, Gradec, 1972.

Hassig, D., Medieval Bestiaries, Text, Image, Ideology, Cambridge, 1995.

Henkel, A. in Schöne, A. (izd.), Emblemata, Handbuch zur Sinnbildkunst des 16. und 17. Jahrhunderts, Stuttgart, 1976.

Henkel, N., Studien zum Physiologus im Mittelalter, Tübingen, 1976. 
James, M. R., The Bestiary, Oxford, 1928.

Lauchert, F., Geschichte des Physiologus, Strassburg,1889.

Lubac, H. de, Exégèse Médiévale, Pariz, 1964.

Mâle, Emile, Lart religieux en XIII siècle en France, Pariz, 1910.

Marino Ferro, X. R., Symboles animaux, Pariz, 1996.

McCulloch, F., Mediaeval Latin and French Bestiaries, Chapel Hill, 1962.

Muratova, X., The Medieval Bestiary, Moskva, 1984.

Muratova, X., I Manoscriti miniati del Bestiario medievale..., Settimane di studio del Centro italiano di studi sullalto medioevo 31, vol. 2, Spoleto, 1985.

Offermanns, D., Der Physiologus nach den Handschriften $G$ und M, Meisneheim, 1966.

Perrig, A., Der Löwe des Villard de Honnecourt. Überlegungen zum Thema "Kunst und Wissenschaft", v: Musagetes. Festschrift für Wolfram Prinz, ur. R. G. Kecks, Berlin, 1991.

Puppi, L. (ur.), Pisanello. Una poetica dell'inatteso, Milano, 1996.

Sarton, G., The Appreciation of Ancient and Medieval Science during the Renaissance (1450-1600), University of Pennsylvania Press, 1995.

Sbordone, F., Richerche sulle fonti e sulla compositione del Physiologus greco, Neapelj, 1936.

Scheller, R. W., Exemplum. Model-Book Drawings and the Practice of Artistic Transmission in the Middle Ages (ca. 900 - 1450), Amsterdam, 1995.

Voisenet, J., Bestiaire chrétien. L'imagerie animale des auteurs du Haut Moyen Âge ( $V^{e}-X I^{e}$ s. ), Toulouse, 1994.

Welter, Th., Lexemplum dans la littérature religieuse et didactique du moyen âge, Pariz, 1927. 


\title{
PLINY'S NATURALIS HISTORIA AND MEDIEVAL ANIMAL ICONOGRAPHY
}

Keywords: medieval animal iconography, Pliny the Elder, Naturalis Historia, bestiaries, Villard de Honnecourt

\begin{abstract}
Most experts accept the influence of Pliny the Elder on the development of medieval animal iconography as completely logical. However, an overview of relevant literature reveals that the generally acknowledged influence of Naturalis Historia is a cliché that most writers cite uncritically, whereas the study of the actual role of Pliny the Elder in the formation of the symbolic meanings of animals is still in its infancy. An accurate comparison of integral texts from Pliny's Naturalis Historia, Aelian's De Natura Animalium, Oppian's Cynegetica and Halieutica, Solinus' Collectanea Rerum Memorabilium, Isidore of Seville's Etymologiae, the Physiologus, and medieval bestiaries shows that writers of medieval bestiaries cited a large amount of Pliny's animal descriptions through the mediation of Aelian, Oppian, Solinus, and Isidore of Seville, who drew their knowledge of natural science almost entirely from Pliny's works. Thus, his direct influence is difficult to prove, but the influence of Plinian content that helped form medieval animal iconography through various mediators can be established with greater certainty.

Studying Pliny's influence on animal iconography is rendered additionally difficult because the methods of transferring content from literary tradition into an artistic medium have been insufficiently explored. The most tangible and recognizable is the role of bestiaries; in numerous examples of late Romanesque and Gothic sculptures it is possible to prove the direct influence of animal illuminations and descriptions in bestiaries, in which the method of depiction expresses the awareness of the symbolic value of the animal, which is transferred from the bestiaries into architectural sculpture and other fine arts media. A special role in studying the transfer of allegoric content from bestiaries into medieval animal iconography is
\end{abstract}


played by the written records of medieval artists, which have been rarely preserved, and especially by "pattern books" (Musterbücher), which on the one hand sculptors and painters used as a direct template and, on the other, undoubtedly express the author's knowledge of bestiaries. Thus, the animal drawings from the famous Sketchbook of Villard de Honnecourt indicate that the author was familiar with contemporary bestiaries and found inspiration in them; however, the relations between the drawings - juxtaposition of positively and negatively valued animals - indicates that he also took their symbolic value into account. Villard's Sketchbook reveals an additional interesting detail: his annotation to the drawing of a porcupine reveals the influence of Pliny's Naturalis Historia on the formation of the symbolic meaning of animals because Villard explicitly mentions features of the porcupine that were first mentioned by Pliny the Elder. 